\title{
The Impact of the Thinking Style on Teaching Methods and Academic Achievement
}

\author{
Roland Sahatcija, PhD \\ Department of Informatics and Research Science, \\ Mediterranean University of Albania, Albania \\ Ariel Ora, $M A$ \\ Carleton University, Ottawa, Canada \\ Anxhela Ferhataj, MSc \\ European University of Tirana, Albania
}

Doi: 10.19044/esj.2017.v13n34p16 URL:http://dx.doi.org/10.19044/esj.2017.v13n34p16

\begin{abstract}
Thinking style is an area of interest for researchers. It influences the decision-making of individuals in every aspect of their life. Does thinking style influence the choice of learning methods? What about academic performance? This research paper's objective is to study the impact of thinking styles on the methods of teaching and academic achievement. There are 186 Albanian university students who participated in the study. The questionnaires were distributed online during the second semester of the 2016-2017 academic year. SPSS 20 and JASP 0.8.1.2 were used for data analysis. The statistical analyses utilized are as follows: distribution table, crossed tabulation, Pearson correlation coefficient, One-Way ANOVA, comparison of means, regression analysis.

The study concluded that thinking style has an impact on academic achievement and not on teaching methods. The largest number of students belong to the concrete-sequential category. An additional conclusion is that students who apply different types of thinking rate the hybrid learning as most effective.
\end{abstract}

Keywords: Thinking style, online learning, hybrid learning, traditional learning, academic achievement

\section{Introduction}

Technological advancements have considerably improved education. The evolution of technology has helped increase the quality and professionalism of teaching in universities. Its impacts are multifold. Nowadays, there exist three types of instruction: the online learning, the 
hybrid learning, and the traditional learning. Researchers have focused their efforts in studying these teaching methods. They argue that of the three teaching methods, the most advantageous methods to be used in continuation are the hybrid and online learning (Anderson, Boyles, \& Rainie, 2012; Güzera \& Canera, 2014; Dziuban, Graham, \& Picciano, 2014). It is the student's responsibility to choose a preferred teaching method to study. Does the thinking style impact in the selection of a teaching method? Does it impact academic achievement? The purpose of this study is to provide answers to the questions above. The objective of this research is to analyze the impact of thinking styles on the teaching methods and academic achievement.

\section{Literature Review}

Teaching methodology is an area of interest for researchers. According to researchers, the hybrid learning is more effective than the other two, the online and traditional learning (Promsurin \& Vitayapirak, 2015; Dziuban, Graham, \& Picciano, 2014; Jasim, Sherbiny, \& Guirguis, 2015; Stockwell, Stockwell, Cennamo, \& Elise, 2015). Additionally, a number of empirical studies have concluded that students who pursued courses through the hybrid learning were more satisfied than students who learned through the other two teaching methods (Castle \& McGuire, 2010; Collopy \& Arnold, 2009; Farley, Jain, \& Thomson, 2011; Martinez-Caro \& Campuzano-Bolarin, 2011; Owston, Garrison, \& Cook, 2006; Schuhmann \& Skopek, 2009; Woltering, Herrler, Spitzer, \& Spreckelsen, 2009). The introduction of new teaching methods in the learning process has a positive impact on the students' academic performance (Fitzgerald \& $\mathrm{Li}, 2015$; Morris, 2010; Owston, York, \& Murtha, 2013). Moreover, they have an impact on the development of decision-making skills (Amador, Miles, \& Peters, 2006). The utilization of contemporary teaching methods has an impact on the development of the student's personality, new skills, and the improvement of academic performance (Smith, Cavanaugh, Jones, Venn, \& Wilson, 2006).

Thinking style is different for every student. Students apply their skills in different ways. The application of skills in various ways is called a thinking style. Considerable research has been conducted in this field, however, more work is needed in order to explain certain aspects. The ways in which the human brain functions are yet to be explained. However, there exist ways in which to determine thinking styles (Sternberg, Grigorenko, \& Zhang, 2008; Sternberg, Thinking styles, 1997; Zhang \& Sternberg, 2005; Gregorc, 2017). One of the researchers to have contributed in the field is Anthony Gregorc, who developed in 1984 the concept of the mind style. According to Gregorc (2017) mind styles are divided in two groups: 
perceptual abilities and ordering abilities. Perceptual abilities are divided into concrete (the five senses) and abstract (understanding ideas and qualities which cannot be seen). This research will use the Gregorc (2017) classification, which consists of four categories: concrete-sequential, concrete random, abstract-sequential, abstract-random. Students who belong to the concrete-sequential manage information following a step after step logical sequence, they prefer working within a solitary and structured environment, and following directions and procedures. Students belonging to the concrete-random prefer risk, experimenting, use their intuition and solve problems independently. Students belonging to abstract-sequential prefer applying detailed analysis before making a decision or acting, uses logic in order to solve problems and likes their opinion to be heard. Students belonging to the abstract-random, prefers focusing on issues at hand, work in group activities, likes to listen to others and establish harmonious relationships with colleagues. According to Al Maghraby and Alshami (2013) the existing correlations between the teaching methods and thinking styles are insignificant. Thinking styles have an impact on academic achievement (Zhang L. , 2002).

The research questions are:

1. Which thinking styles are preferred by students?

2. Which teaching method is valued most by students?

3. Does thinking style have an impact on teaching methods and academic achievement?

Research hypotheses are:

- H1: Students have the same evaluation of teaching methods regardless of thinking style $(\alpha=0.05)$.

- $\quad \mathrm{H} 2$ : Elements of teaching methods are evaluated the same regardless of thinking style $(\alpha=0.05)$.

- H3: All three teaching methods are evaluated effective the same by students regardless thinking style $(\alpha=0.05)$.

- H4: Students have the same academic achievement regardless of thinking style $(\alpha=0.05)$.

- H5: Academic achievement do not have an impact on student perception of teaching methods $(\alpha=0.05)$. 
This study employs the following conceptual model:

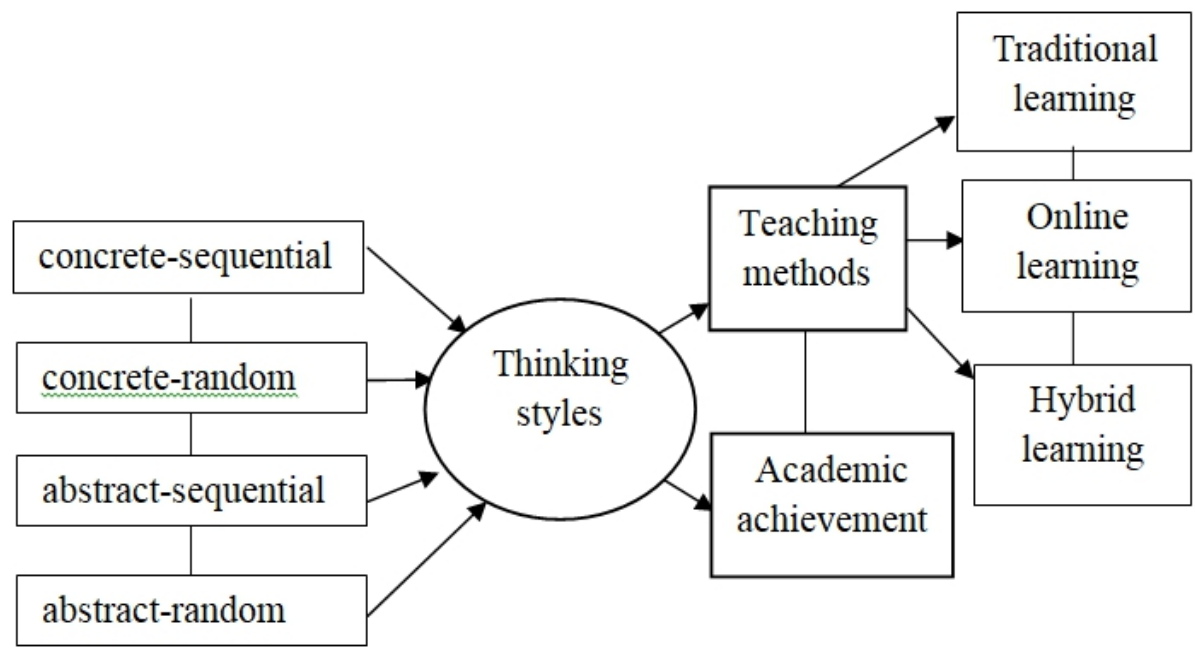

\section{Methodology}

The descriptive method and the quantitative analysis have been utilized in this study. The questionnaire was employed for the collection of data (Gregorc, 2017; O'Malley \& McCraw, 2001), which was distributed online. The questionnaire consists of 12 questions divided into three sections. The first part contains questions with alternatives on thinking styles. The second part contains a 6-point Likert scale survey, ranging from "Not Applicable" to "Strongly Agree". The third part contains demographic questions. The study was conducted during the second semester of the 20162017 year. 186 Albanian university students participated in this study. The response return rate was $90 \%$. The data from the study sample are reflected in the graphs below.

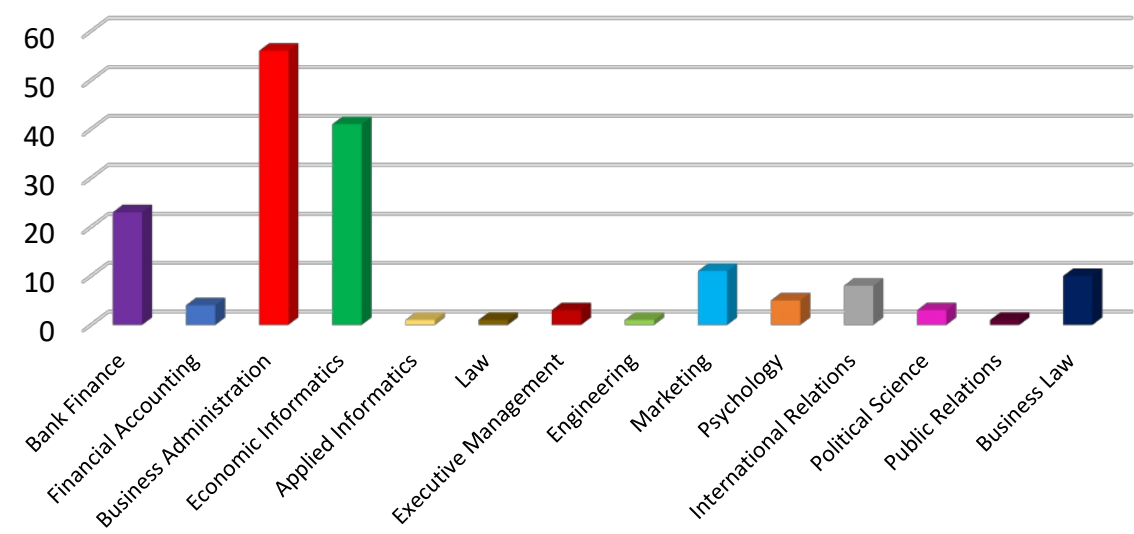

Graph 1: Study area 

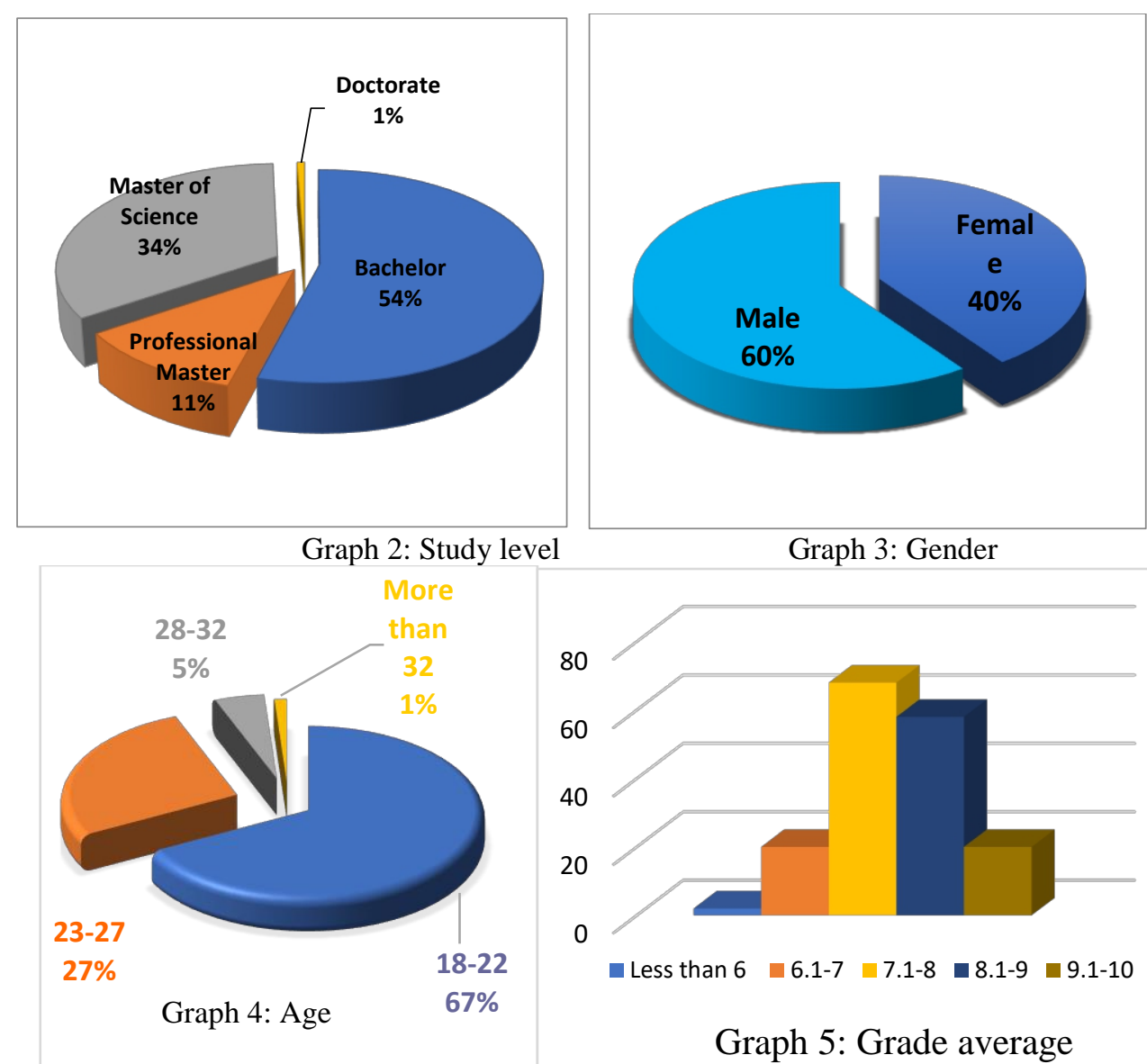

Graph 3: Gender

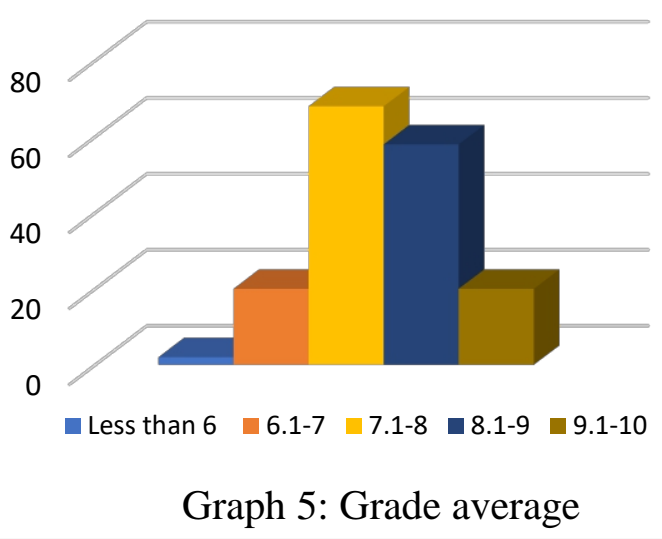

The data was analyzed with SPSS 20 and JASP-0.8.1.2. The value of the reliability coefficient Cronbach's $\alpha$ is 0.825 . This shows the obtained data are valid for research purposes. Table 2 provides the coefficient's values of the three variables.

\begin{tabular}{cc} 
Table 1: Reliability coefficient \\
\hline \multicolumn{2}{c}{ Cronbach's $\alpha$} \\
\hline scale & 0.825 \\
\hline Note. Of the observations, 168 were und 0 were exchuded
\end{tabular}

Note. Of the observations, 168 were used, 0 were excluded list-wise, and 168 were provided.

Table 2: Reliability coefficient of each variable

\begin{tabular}{cc}
\hline & If item dropped \\
\cline { 2 - 2 } & Cronbach's $\alpha$ \\
\hline Teaching method & 0.818 \\
Thinking style & 0.836 \\
Academic achievement & 0.829 \\
\hline
\end{tabular}




\section{Empirical Analysis}

Descriptive statistics provides detailed information with respect to variables. Table 3 data shows that the hybrid learning has the highest mean. Whereas the online learning has the lowest standard deviation. It must be noted that the values of standard deviation are low. This conveys that the data are distributed around the mean.

Table 3: Descriptive data

\begin{tabular}{cccccc}
\hline & $\begin{array}{c}\text { Traditional } \\
\text { learning }\end{array}$ & $\begin{array}{c}\text { Online } \\
\text { learning }\end{array}$ & $\begin{array}{c}\text { Hybrid } \\
\text { learning }\end{array}$ & Thinking style & $\begin{array}{c}\text { Academic } \\
\text { achievement }\end{array}$ \\
\hline Valid & 168 & 168 & 168 & 168 & 168 \\
Missing & 0 & 0 & 0 & 0 & 0 \\
Mean & 4.196 & 3.946 & 4.280 & 2.161 & 3.440 \\
Std. Error of & 0.06608 & 0.05926 & 0.06536 & 0.08909 & 0.06896 \\
$\quad$ Mean & & 0.7681 & 0.8472 & 1.155 & 0.8938 \\
Std. Deviation & 0.8565 & 1.000 & 1.000 & 1.000 & 1.000 \\
Minimum & 2.000 & 6.000 & 6.000 & 4.000 & 5.000 \\
Maximum & 6.000 & & & & \\
\hline
\end{tabular}

\section{Which thinking styles are preferred by students?}

According to the data from Table 4, most students identify with the concrete-sequential. The number of students using concrete-random is the same with students who use abstract-sequential. Last, there are students who belong to the abstract-random.

Table 4: Preferences of thinking styles

\begin{tabular}{ccccc}
\hline & Frequency & Percent & Valid Percent & Cumulative Percent \\
\hline concrete-sequential & 69 & 41.1 & 41.1 & 41.1 \\
concrete random & 34 & 20.2 & 20.2 & 61.3 \\
abstract-sequential & 34 & 20.2 & 20.2 & 81.5 \\
abstract-random & 31 & 18.5 & 18.5 & 100.0 \\
Total & 168 & 100.0 & 100.0 & \\
\hline
\end{tabular}

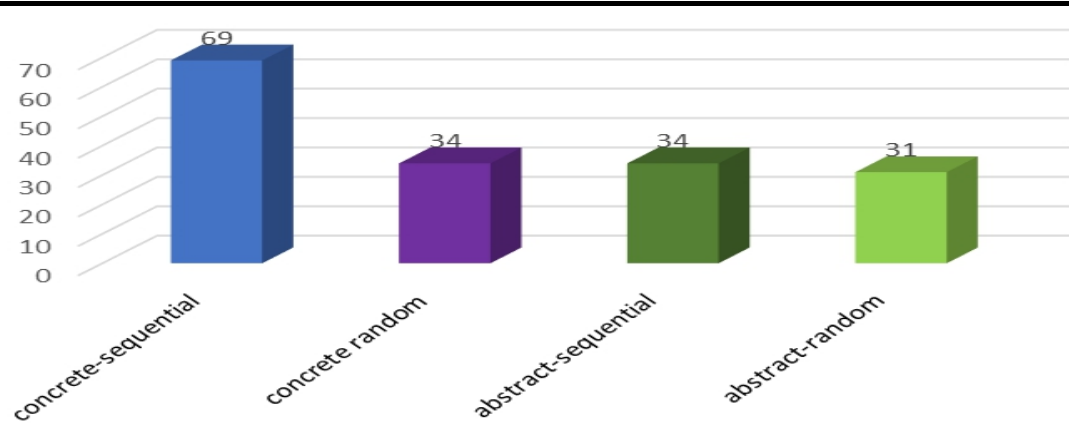

Graph 6: Thinking style

Concrete-sequential is most used by both genders, however, preference changes in the case of other thinking styles. The thinking style 
least used by male students is abstract-random while the thinking style least used by female students is concrete-random. The value of the test chi-square $(p=0.047<p=0.05)$ shows that student gender has an impact on thinking style. Table 5 provides detailed information.

Table 5: Thinking style and gender

\begin{tabular}{cccc}
\hline & \multicolumn{2}{c}{ Gender: } & \multirow{2}{*}{ Total } \\
\cline { 2 - 4 } Thinking style & Female & Male & 69 \\
concrete-sequential & 36 & 33 & 34 \\
concrete random & 9 & 25 & 34 \\
abstract-sequential & 11 & 23 & 31 \\
abstract-random & 11 & 20 & 168 \\
Total & 67 & 101 & \\
& \multicolumn{2}{c}{$\mathrm{p}$} \\
Chi-Squared Tests & Value & df & \multicolumn{2}{c}{0.047} \\
$\mathrm{X}^{2}$ & 7.953 & 3 & \multicolumn{2}{c}{} \\
\hline
\end{tabular}

The preferences of students on thinking styles differ from one area to the other. A large number of students belong to the concrete-sequential and abstract-sequential (Table 6). It must be noted that concrete-sequential thinking style is first. Study area has an impact on thinking style as shown by value of $\mathrm{p}$, which is less than 0.05 .

Table 6: Thinking style and study area

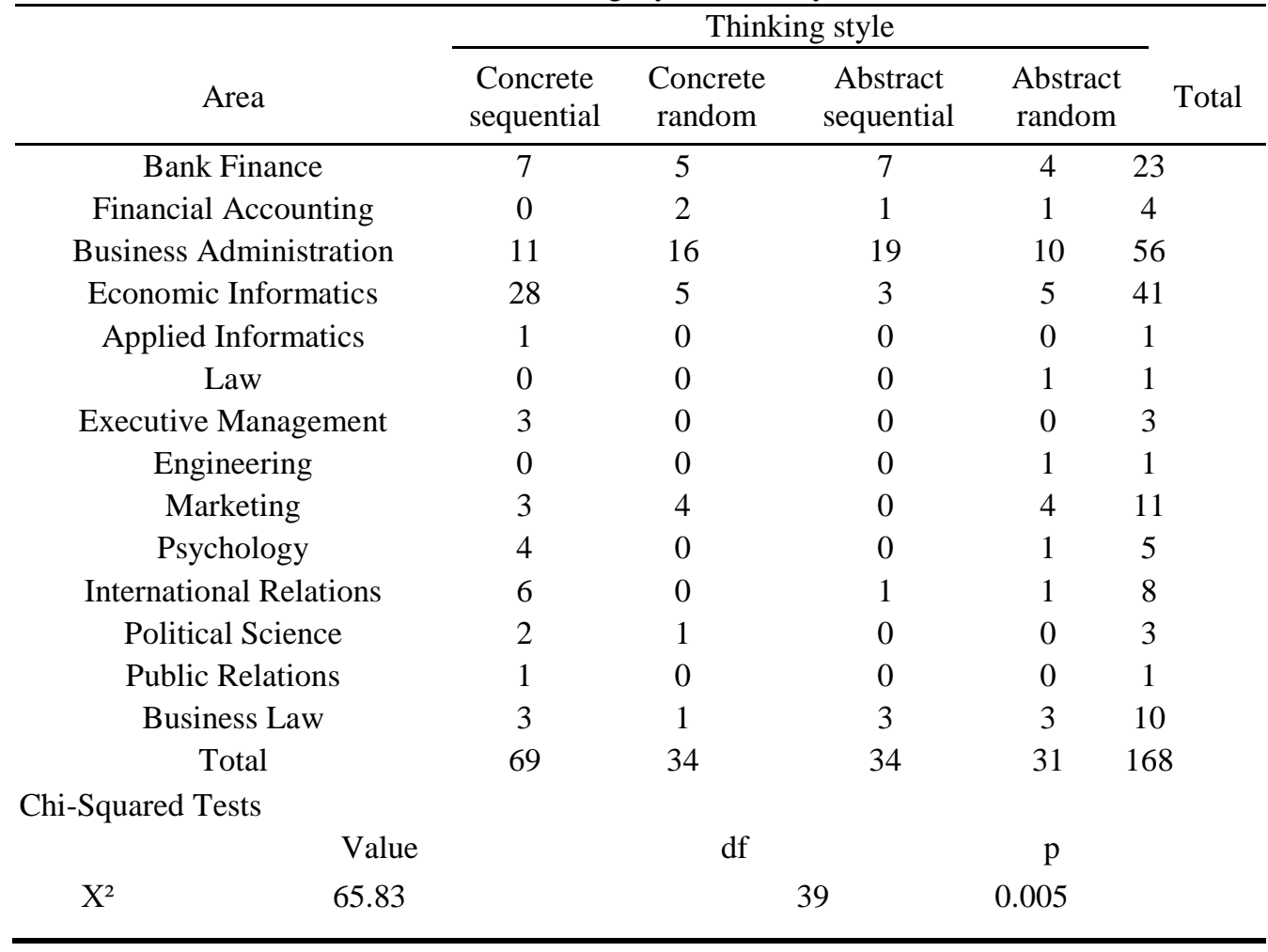


The greatest part of the surveyed students belongs to 18-22 age band. The concrete-sequential is used most by students. Age does not have an impact on thinking style since the value of $\mathrm{p}=0.144$ is greater than 0.05 . Table 7 shows students' preferences on thinking styles based on age.

Table 7: Thinking style and age

\begin{tabular}{|c|c|c|c|c|c|c|c|}
\hline & & & \multicolumn{4}{|c|}{ Age } & \multirow[b]{2}{*}{ Total } \\
\hline \multicolumn{3}{|c|}{ Thinking style } & $18-22$ & $23-27$ & $28-32$ & Over 32 & \\
\hline \multicolumn{3}{|c|}{ concrete-sequential } & 40 & 26 & 2 & 1 & 69 \\
\hline \multirow{3}{*}{\multicolumn{3}{|c|}{$\begin{array}{l}\text { concrete random } \\
\text { abstract-sequential } \\
\text { abstract-random }\end{array}$}} & 23 & 9 & 2 & 0 & 34 \\
\hline & & & 29 & 4 & 1 & 0 & 34 \\
\hline & & & 21 & 6 & 3 & 1 & 31 \\
\hline \multicolumn{3}{|c|}{ Total } & 113 & 45 & 8 & 2 & 168 \\
\hline \multicolumn{8}{|c|}{ Chi-Squared Tests } \\
\hline \multicolumn{4}{|c|}{ Value } & \multicolumn{2}{|r|}{ df } & \multicolumn{2}{|c|}{$\mathrm{p}$} \\
\hline $\mathrm{X}^{2}$ & \multicolumn{3}{|c|}{13.42} & \multicolumn{2}{|r|}{9} & \multicolumn{2}{|c|}{0.144} \\
\hline
\end{tabular}

The concrete-sequential is ranked first by all students regardless of academic performance. The following ranking of the other thinking styles differs in accordance with academic achievement. Based on the conclusions of the study the concrete-sequential is preferred most by students. Table 8 provides detailed rankings in accordance with academic achievement.

Table 8: Thinking style and academic achievement

\begin{tabular}{ccccccc}
\hline & \multicolumn{7}{c}{ Academic achievement } \\
\cline { 2 - 7 } Thinking style & Less than 6 & $6.1-7$ & $7.1-8$ & $8.1-9$ & $9.1-10$ & Total \\
\hline concrete-sequential & 1 & 9 & 27 & 20 & 12 & 69 \\
concrete random & 0 & 2 & 16 & 14 & 2 & 34 \\
abstract-sequential & 1 & 6 & 14 & 10 & 3 & 34 \\
abstract-random & 0 & 3 & 11 & 14 & 3 & 31 \\
Total & 2 & 20 & 68 & 58 & 20 & 168 \\
\hline
\end{tabular}

\section{Which teaching method is valued most by students?}

The hybrid learning scores highest among students with grade average 4.280 (Table 9). It is followed by the traditional learning with grade average 4.196 and the online learning with average 3.946. The online learning received the lowest evaluation.

Table 9: Teaching methods

\begin{tabular}{ccccc}
\hline & $\mathrm{N}$ & Mean & SD & SE \\
\hline Traditional learning & 168.0 & 4.196 & 0.857 & 0.066 \\
Online learning & 168.0 & 3.946 & 0.768 & 0.059 \\
Hybrid learning & 168.0 & 4.280 & 0.847 & 0.065 \\
\hline
\end{tabular}




\section{Does thinking style have an impact on teaching methods and academic achievement?}

It is concluded through the values of the Pearson correlation coefficient in Table 10, that thinking styles do not have an impact on teaching methods, however they impact academic achievement. Thinking style has an insignificant negative correlation to teaching methods where $\mathrm{p}$ $=0.329(-0.076)$. Between thinking styles and academic achievement there exist a significant statistical correlation with correlation coefficient 0.205 and $\mathrm{p}=0.008$. Thus, the analysis concludes that thinking style impacts only academic achievement.

Table 10: Pearson Correlations

\begin{tabular}{ccccc}
\hline & & $\begin{array}{c}\text { Thinking } \\
\text { styles }\end{array}$ & $\begin{array}{c}\text { Teaching } \\
\text { methods }\end{array}$ & $\begin{array}{c}\text { Academic } \\
\text { achievement }\end{array}$ \\
\hline \multirow{2}{*}{ Thinking styles } & Pearson's r & - & -0.076 & $0.205^{* *}$ \\
& p-value & - & 0.329 & 0.008 \\
Teaching methods & Pearson's r & - & $-0.163^{*}$ \\
& p-value & - & 0.035 \\
Academic achievement & Pearson's r & & - \\
& p-value & & - \\
\hline
\end{tabular}

$* \mathrm{p}<.05, * * \mathrm{p}<.01, * * * \mathrm{p}<.001$

H1: Students have the same evaluation of teaching methods regardless of thinking style $(\alpha=0.05)$.

In Table 11 the values of Sig are greater than $\alpha=0.05$. This conveys that there do not exist differences in the evaluations of students, as a result hypothesis $\mathrm{H} 1$ is supported with confidence interval $95 \%$.

\begin{tabular}{|c|c|c|c|c|c|c|}
\hline \multicolumn{7}{|c|}{ Table 11- One- Way ANOVA } \\
\hline & & $\begin{array}{l}\text { Sum of } \\
\text { Squares }\end{array}$ & df & $\begin{array}{l}\text { Mean } \\
\text { Square }\end{array}$ & $\mathrm{F}$ & Sig. \\
\hline \multirow[t]{3}{*}{$\begin{array}{l}\text { Traditional } \\
\text { learning }\end{array}$} & $\begin{array}{c}\text { Between } \\
\text { Groups }\end{array}$ & 1.660 & 3 & .553 & .751 & .523 \\
\hline & Within Groups & 120.858 & 164 & .737 & & \\
\hline & Total & 122.518 & 167 & & & \\
\hline \multirow[t]{3}{*}{ Online learning } & $\begin{array}{l}\text { Between } \\
\text { Groups }\end{array}$ & 3.661 & 3 & 1.220 & 2.110 & .101 \\
\hline & Within Groups & 94.857 & 164 & .578 & & \\
\hline & Total & 98.518 & 167 & & & \\
\hline \multirow[t]{3}{*}{ Hybrid learning } & $\begin{array}{l}\text { Between } \\
\text { Groups }\end{array}$ & 5.266 & 3 & 1.755 & 2.512 & .060 \\
\hline & Within Groups & 114.586 & 164 & 699 & & \\
\hline & Total & 119.851 & 167 & & & \\
\hline
\end{tabular}

H2: Elements of teaching methods are evaluated the same regardless of thinking style $(\alpha=0.05)$.

Thinking style does not have an impact on the evaluation of teaching methods. Values of Sig of the three teaching methods are higher than 
$\alpha=0.05$. Therefore, it is concluded that hypothesis $\mathrm{H} 2$ is supported with confidence interval $95 \%$.

\begin{tabular}{|c|c|c|c|c|c|c|}
\hline \multicolumn{7}{|c|}{ Table 12- One- Way ANOVA } \\
\hline & & $\begin{array}{l}\text { Sum of } \\
\text { Squares }\end{array}$ & $\mathrm{df}$ & $\begin{array}{l}\text { Mean } \\
\text { Square }\end{array}$ & $\mathrm{F}$ & Sig. \\
\hline \multirow[t]{3}{*}{$\begin{array}{c}\text { Traditional } \\
\text { learning }\end{array}$} & $\begin{array}{c}\text { Between } \\
\text { Groups }\end{array}$ & 2.381 & 3 & .794 & .817 & .486 \\
\hline & $\begin{array}{l}\text { Within } \\
\text { Groups }\end{array}$ & 159.327 & 164 & .972 & & \\
\hline & Total & 161.708 & 167 & & & \\
\hline \multirow[t]{3}{*}{ Online learning } & $\begin{array}{c}\text { Between } \\
\text { Groups }\end{array}$ & 1.508 & 3 & .503 & .607 & .612 \\
\hline & $\begin{array}{l}\text { Within } \\
\text { Groups }\end{array}$ & 135.897 & 164 & .829 & & \\
\hline & Total & 137.405 & 167 & & & \\
\hline \multirow[t]{3}{*}{ Hybrid learning } & $\begin{array}{c}\text { Between } \\
\text { Groups }\end{array}$ & 4.067 & 3 & 1.356 & 1.861 & .138 \\
\hline & $\begin{array}{l}\text { Within } \\
\text { Groups }\end{array}$ & 119.451 & 164 & .728 & & \\
\hline & Total & 123.518 & 167 & & & \\
\hline
\end{tabular}

H3: All three teaching methods are evaluated effective the same by students regardless thinking style $(\alpha=0.05)$.

Students evaluate the hybrid learning as the most effective method of the three teaching methods. Students belonging to different styles of thinking have different evaluations of teaching methods. Value of Sig of the hybrid learning is 0.039 , thus less than $\alpha=0.05$. With respect to the other two teaching methods, there do not exist significant differences ( $\mathrm{Sig}=0.288$ and 0.447). The analysis concludes that hypothesis $\mathrm{H} 3$ is rejected.

\begin{tabular}{|c|c|c|c|c|c|c|}
\hline \multicolumn{7}{|c|}{ Table 13- One- Way ANOVA } \\
\hline & & $\begin{array}{c}\text { Sum of } \\
\text { Squares }\end{array}$ & $\mathrm{df}$ & $\begin{array}{l}\text { Mean } \\
\text { Square }\end{array}$ & $\mathrm{F}$ & Sig. \\
\hline \multirow[t]{3}{*}{$\begin{array}{c}\text { Traditional } \\
\text { learning }\end{array}$} & $\begin{array}{c}\text { Between } \\
\text { Groups }\end{array}$ & 3.553 & 3 & 1.184 & 1.266 & .288 \\
\hline & $\begin{array}{l}\text { Within } \\
\text { Groups }\end{array}$ & 153.393 & 164 & .935 & & \\
\hline & Total & 156.946 & 167 & & & \\
\hline \multirow[t]{3}{*}{ Online learning } & $\begin{array}{c}\text { Between } \\
\text { Groups }\end{array}$ & 1.977 & 3 & .659 & .891 & .447 \\
\hline & $\begin{array}{l}\text { Within } \\
\text { Groups }\end{array}$ & 121.356 & 164 & .740 & & \\
\hline & Total & 123.333 & 167 & & & \\
\hline \multirow[t]{3}{*}{ Hybrid learning } & $\begin{array}{c}\text { Between } \\
\text { Groups }\end{array}$ & 7.655 & 3 & 2.552 & 2.861 & .039 \\
\hline & $\begin{array}{l}\text { Within } \\
\text { Groups }\end{array}$ & 146.250 & 164 & .892 & & \\
\hline & Total & 153.905 & 167 & & & \\
\hline
\end{tabular}


H4: Students have the same academic achievement regardless of thinking style $(\alpha=0.05)$.

Students who belong to abstract-random have the highest academic achievement with a mean value $=3.55$. Second place, is concrete-sequential with a mean of 3.48. Third place, is concrete-random with mean 3.47. Last, is abstract-sequential with mean 3.24. It is inferred from the values that there exist differences in the mean value between thinking styles thus, hypothesis $\mathrm{H} 4$ is rejected.

\begin{tabular}{|c|c|c|c|c|c|}
\hline \multicolumn{7}{|c|}{ Table 13: Comparison of means } \\
\hline Thinking styles & Mean & $\mathrm{N}$ & $\begin{array}{c}\text { Std. } \\
\text { Deviation }\end{array}$ & $\begin{array}{c}\text { Std. Error of } \\
\text { Mean }\end{array}$ & $\begin{array}{c}\% \text { of Total } \\
\text { Sum }\end{array}$ \\
\hline concrete-sequential & 3.48 & 69 & .979 & .118 & $41.5 \%$ \\
\hline concrete random & 3.47 & 34 & .706 & .121 & $20.4 \%$ \\
\hline abstract-sequential & 3.24 & 34 & .955 & .164 & $19.0 \%$ \\
\hline abstract-random & 3.55 & 31 & .810 & .145 & $19.0 \%$ \\
\hline Total & 3.44 & 168 & .894 & .069 & $100.0 \%$ \\
\hline
\end{tabular}

H5: Academic achievement do not have an impact on student perception of teaching methods $(\alpha=0.05)$.

The regression analysis shown in Table 14 concludes that academic achievement explain $33.3 \%$ of the variance of the perception of teaching methods, where Adjusted $\mathrm{R}^{2}=0.333, \mathrm{~F}=84.32$ and $\mathrm{p}<0.001$. Academic achievement have an impact on students' perception of teaching methods. Between the two variables there exists a strong positive and significant correlation with coefficient Beta $=0.580, \mathrm{t}=9.183$ and $\mathrm{p}<0.001$ (Table 15). Hypothesis H5 is rejected.

Table 14: Regression analysis

\begin{tabular}{cccccccccc}
\hline Model & $\mathrm{R}$ & $\mathrm{R}^{2}$ & Adjusted $\mathrm{R}^{2}$ & RMSE & $\mathrm{R}^{2}$ Change & F Change & df1 & df2 & $\mathrm{p}$ \\
\hline 1 & 0.580 & 0.337 & 0.333 & 0.478 & 0.337 & 84.32 & 1 & 166 & $<.001$ \\
\hline
\end{tabular}

Table 15: Regression analysis between academic achievement and the perception of learning methods

\begin{tabular}{ccccccc}
\hline Model & & $\begin{array}{c}\text { Unstandardized } \\
\beta\end{array}$ & $\begin{array}{c}\text { Standard } \\
\text { Error }\end{array}$ & $\begin{array}{c}\text { Standardized } \\
\beta\end{array}$ & $\mathrm{t}$ & $\mathrm{p}$ \\
\hline \multirow{3}{*}{1} & $\begin{array}{c}\text { (Constant) } \\
\text { Academic } \\
\text { achievement }\end{array}$ & 2.121 & 0.224 & & $9.477<.001$ \\
& 0.489 & 0.053 & 0.580 & $9.183<.001$ \\
\hline
\end{tabular}

\section{Conclusion and Recommendations}

-In this study there are four categories of thinking style: 1-Concretesequential thinking style, 2-Concrete random thinking style, 3-Abstractsequential thinking style, 4-Abstract-random thinking style. Students use most the first thinking style, namely Concrete-sequential thinking style. The other thinking styles are also used by students. 
-The chi-square test score $(\mathrm{p}=0.047<0.05)$ indicates that the student's gender have an impact on the thinking style. The study area have an impact on thinking styles referring to the value of $\mathrm{p}=0.005$, which is less than 0.05 .

-Thinking style does not have an impact in the selection of teaching methods, however it has an impact on academic achievement. This conclusion is in the same line with the conclusions reached by other researchers. Students belonging to different thinking styles have the same perception of teaching methods and the elements of these teaching methods. -The next conclusion is that the evaluation on effectiveness of teaching methods is not the same.

-The hybrid learning is evaluated as more effective than the other two teaching methods.

-Students who use abstract-random have better academic performance compared to students who use other thinking styles.

-Academic achievement explain $33.3 \%$ of the variance of perception of teaching methods.

-Universities need to start planning on how to apply contemporary teaching methods, like online learning and hybrid learning.

-Another recommendation is to implement classes in accordance to thinking style (where classes are specialized with modern logistic) in order for the learning process to be more effective.

\section{References:}

1. Al Maghraby, M. A., \& Alshami, A. M. (2013). Learning style and teaching method preferences of Saudi students of physical therapy. Journal of Family and Community Medicine, 20(3), 192-197. Retrieved September 13, 2017

2. Amador, J. A., Miles, L., \& Peters, C. B. (2006). The practice of problem-based learning: A guide to implementing PBL in the college classroom. Bolton: Anker Publishing Co.

3. Anderson, J. Q., Boyles, J. L., \& Rainie, L. (2012). The future impact of the Internet on higher education: Experts expect more-efficient collaborative environments and new grading collaborative environments and new grading courses, the shift away from oncampus life. Washington, D.C.: Pew Research Center's Internet \& American Life Project. Retrieved June 14, 2017

4. Castle, S. R., \& McGuire, C. J. (2010). An analysis of student selfassessment of online, blended, and face-to-face learning environments: Implications for sustainable education delivery. International Education Studies, 3(3), 36-40. Retrieved June 15, 2017

5. Collopy, R. M., \& Arnold, J. M. (2009). To blend or not to blend: Online and blended learning environments in undergraduate teacher 
education. Issues in Teacher Education, 18(2), 85-101. Retrieved June 15,2017

6. Dziuban, C., Graham, C., \& Piçiano, A. (2014). Blended learning: Research perspectives. New York: Routledge.

7. Farley, A., Jain, A., \& Thomson, D. (2011). Blended learning in finance: Comparing student perceptions of lectures, tutorials and online learning environments across different year levels. Economic Papers, 30(1), 99-108. Retrieved June 15, 2017

8. Fitzgerald, N., \& Li, L. (2015, July 31). Using Presentation Software To Flip an Undergraduate Analytical Chemistry Course. Journal of Chemical Education, 92(9), 1559-1563. Retrieved June 8, 2017

9. Gregorc, A. F. (2017, September 13). Mind Styles - Anthony Gregorc. Retrieved from Mind Styles - Anthony Gregorc: http://web.cortland.edu/andersmd/learning/gregorc.htm

10. Güzera, B., \& Canera, H. (2014). The past, present and future of blended learning: an in depth analysis of literature. Social and Behavioral Sciences, 4596 - 4603. Retrieved June 12, 2017

11. Jasim, M. A., Sherbiny, M. M., \& Guirguis, S. K. (2015, July). Evaluation of E-Learning Program versus Traditional Education Instruction for Undergraduate. International Journal of Advanced Research in Science, Engineering and Technology, 2(7), 776-786. Retrieved June 12, 2017

12. Martinez-Caro, E., \& Campuzano-Bolarin, F. (2011). Factors affecting students' satisfaction in engineering disciplines: Traditional vs. blended approaches. European Journal of Engineering Education, 36(5), 473-483. Retrieved June 15, 2017

13. Morris, N. (2010). Blended learning approaches enhance student academic performance. International Conference (Hong Kong University, 2010) Enhancing Learning Experiences in Higher Education (p. Proceedings of Enhancing Learning Experiences in Higher Education). Hong Kong: Hong Kong University. Retrieved June 14, 2017

14. O'Malley, J., \& McGraw, H. (2001, June 20). Students Perceptions of Distance Learning, Online Learning and the Traditional Classroom. Retrieved July 9, 2017, from http://www.westga.edu/ distance/omalley24.html

15. Owston, R. D., Garrison, D. R., \& Cook, K. (2006). Blended learning at Canadian universities: Issues and practices. In C. J. Bonk, \& C. R. Graham, The handbook of blended learning: Global perspectives, local designs (pp. 338-350). San Francisco: Pfeiffer. Retrieved June 15,2017 
16. Owston, R., York, D., \& Murtha, S. (2013). Student perceptions and achievement in a university blended learning strategic initiative. The Internet and Higher Education, 18, 38-46. Retrieved June 15, 2017

17. Promsurin, S., \& Vitayapirak, J. (2015). Comparison of e-Learning, Blended and Traditional English Teaching Methods: A Case Study of Ban Hong Community Education College. International Journal of Languages, Literature and Linguistics, 1(2), 80-86. Retrieved June 12, 2017

18. Schuhmann, R. A., \& Skopek, T. A. (2009). Blurring the lines: A blended learning model in a graduate public administration program. The Quarterly Review of Distance Education, 10(2), 219-232. Retrieved June 15, 2017

19. Smith, A. J., Cavanaugh, C., Jones, J., Venn, J., \& Wilson, W. (2006). Influence of learning style on instructional multimedia effects on graduate student cognitive and psychomotor performance. $J$ Allied Health, 35, 182-203.

20. Sternberg, R. J. (1997). Thinking styles. New York: Cambridge University Press.

21. Sternberg, R. J., Grigorenko, E. L., \& Zhang, L.-F. (2008). Styles of learning and thinking matter in instruction and assessment. Perspectives on Psychological Science, 3(6), 486-506. Retrieved September 13, 2017

22. Stockwell, B. R., Stockwell, M. S., Cennamo, M., \& Elise, J. (2015, August 27). Blended Learning Improves Science Education. Cell, 162(5), 933-936. Retrieved June 7, 2017

23. Woltering, V., Herrler, A., Spitzer, K., \& Spreckelsen, C. (2009). Blended learning positively affects students' satisfaction and the role of the tutor in the problem-based learning process: Results of a mixed-method evaluation. Advances in Health Science Education, 14, 725-738. Retrieved June 15, 2017

24. Zhang, L. (2002). Thinking Styles: their relationships with modes of thinking and academic performance. Educational Psychology, 22(3), 331-348. Retrieved September 21, 2017

25. Zhang, L.-F., \& Sternberg, R. J. (2005). A threefold model of intellectual styles. Educational Psychology Review, 17(1), 1-53. Retrieved September 13, 2017 